\title{
Checklist of Diatoms (Bacillariophyceae) from the Southern Gulf of Mexico: Data-Base (1979-2010) and New Records
}

\section{Licea $\mathbf{S}^{1 *}$, Moreno-Ruiz $\mathrm{JL}^{2}$ and Luna $\mathbf{R}^{1}$}

${ }^{1}$ Universidad Nacional Autónoma de México, Institute of Marine Sciences and Limnology, Mexico 04510, D.F., Mexico

${ }^{2}$ Universidad Autónoma Metropolitana-Xochimilco, C.P. 04960, D.F., Mexico

\begin{abstract}
The objective of this study was to compile a coded checklist of 430 taxa of diatoms collected over a span of 30 years (1979-2010) from water and net-tow samples in the southern Gulf of Mexico. The checklist is based on a long-term survey involving the 20 oceanographic cruises. The material for this study comprises water and net samples collected from 647 sites. Most species were identified in water mounts and permanent slides, and in a few cases a transmission or scanning electron microscope was used. The most diverse genera in both water and the net samples were Chaetoceros (44 spp.), Thalassiosira (23 spp.), Nitzschia (25 spp.), Amphora (16 spp.), Diploneis (16 spp.), Rhizosolenia (14 spp.) and Coscinodiscus (13 spp.). The most frequent species in net and water samples were, Actinoptychus senarius, Asteromphalus heptactis, Bacteriastrum delicatulum, Cerataulina pelagica, Chaetoceros didymus, C. diversus, C. lorenzianus, C. pelagicus, C. pseudocurvisetus, Coscinodiscus radiatus, Cyclotella striata, Diploneis bombus, Guinardia flaccida, Hemiaulus sinensis, Leptocylindrus danicus, Odontella aurita, O. mobiliensis, Paralia sulcata, Proboscia alata, Pseudo-nitzschia pseudodelicatissima, P. pungens, Skeletonema costatum, Thalassiosira eccentrica, T. partheneia, Thalassionema nitzschioides, and Thalassiothrix longissima. Ninety three taxa were new records for this region.
\end{abstract}

Keywords: Checklist; Marine diatoms; Data-base; Gulf of Mexico

\section{Introduction}

Diatoms are the most important primary producers of both marine and freshwater environments. Its role in regulating the ocean's silicon cycle is considerable [1]. For taxonomists and ecologists these microalgae are useful for monitoring past and present environmental conditions. They are commonly used in studies of water quality, because they are sensitive to many environmental conditions related to water acidification, eutrophication and climate changes. Diatoms have also been used as valuable indicators in historical assessments of water quality [2-6].

Diatoms (Division Bacillariophyta, Class Bacillariophyceae) have been studied since the early nineteenth century when they were popular among microscopists. In the late nineteenth century many European workers produced hand illustrated monographs and descriptions of species which are still serve as valuable references reviewed in Werner [7]. Hasle and Syvertsen [8] analyzed the new taxonomic information on diatom morphology and presented a revision of the classical identification literature (atlases, floras and handbooks). Krayesky et al. [9] listed 850 diatom species for the entire Gulf of Mexico; however many of them were insufficiently known or, doubtful entities. Besides, several of the species in this list, have other accepted names according to Guiry and Guiry [10], an on-line resource available since September 2004. As a result, only 575 taxa have valid names.

Diatom studies in Mexican waters were recorded by Schmidt et al. [11] in the "Atlas der Diatomacenkunde" with illustrations of 313 species from locations in the Bay of Campeche in the southern Gulf of Mexico. Of these, 108 species were assigned to the genus Navicula, 36 to Amphora, 28 to Campylodiscus and 26 to Triceratium. Additionally, they included some infra-specific taxa that were considered as doubtful cases. Today, many of these names are no longer valid or their taxonomic status has changed. Through the 60's until the 80 's, Soviet and Soviet-Cuban expeditions in the southern Gulf [12] found out that diatoms were the dominant group. Recently, many researchers reported the taxonomy and distribution of diatoms in this region [1320]. However, they did not report many of the small and rare species.
This study is part of a large-scale phytoplankton relational database for the southern part of the Gulf of Mexico. The diatom section of this program comprises 434 diatoms with a total of 14801 entries between June 1979 and December 2010. The objective of this study was to compile a checklist of diatom species from the southern Gulf of Mexico and to provide an update of valid taxonomic names for each one.

\section{Materials and Methods}

\section{The study area}

The study area in the southern Gulf of Mexico (herein referred to as SGM) lies between $24^{\circ} 38^{\prime}$ and $18^{\circ} 15^{\prime} \mathrm{N}$ and between $86^{\circ} 15^{\prime}$ and $98^{\circ} 12^{\prime}$ $\mathrm{W}$ (Figure 1). The hydrographic conditions in this area are greatly influenced by the Loop Current and the detachment of anticyclonic eddies that migrate westward around the Gulf. These eddies tend to move northwards or southwards, depending on the expulsion of water masses. The south region of Campeche Bay has a predominantly cyclonic circulation mainly associated with the Yucatan Channel waters [21]. The presence of cold winds between October and April causes the formation of cold fronts. The dominant cyclonic circulation and fronts of the rivers create a dynamic system which provides the region with a unique environment. The Coatzacoalcos and the Grijalva-Usumacinta rivers represent approximately $11 \%$ of all fluvial discharges into the Gulf of Mexico. There is a notable presence of a permanent cyclonic eddy in the central region and beyond the continental shelf, as well

*Corresponding author: Licea S, Universidad Nacional Autónoma de México, Institute of Marine Sciences and Limnology, Circuito Exterior s/n, Ciudad Universitaria, México 04510, D.F., Mexico, Tel: +52 5622 5689; E-mail: licea@cmarl.unam.mx

Received November 11, 2016; Accepted December 09, 2016; Published December 15, 2016

Citation: Licea S, Moreno-Ruiz JL, Luna R (2016) Checklist of Diatoms (Bacillariophyceae) from the Southern Gulf of Mexico: Data-Base (1979-2010) and New Records. J Biodivers Endanger Species 4: 174. doi: 10.4172/2332-2543.1000174

Copyright: ( 2016 Licea S, et al. This is an open-access article distributed under the terms of the Creative Commons Attribution License, which permits unrestricted use, distribution, and reproduction in any medium, provided the original author and source are credited. 


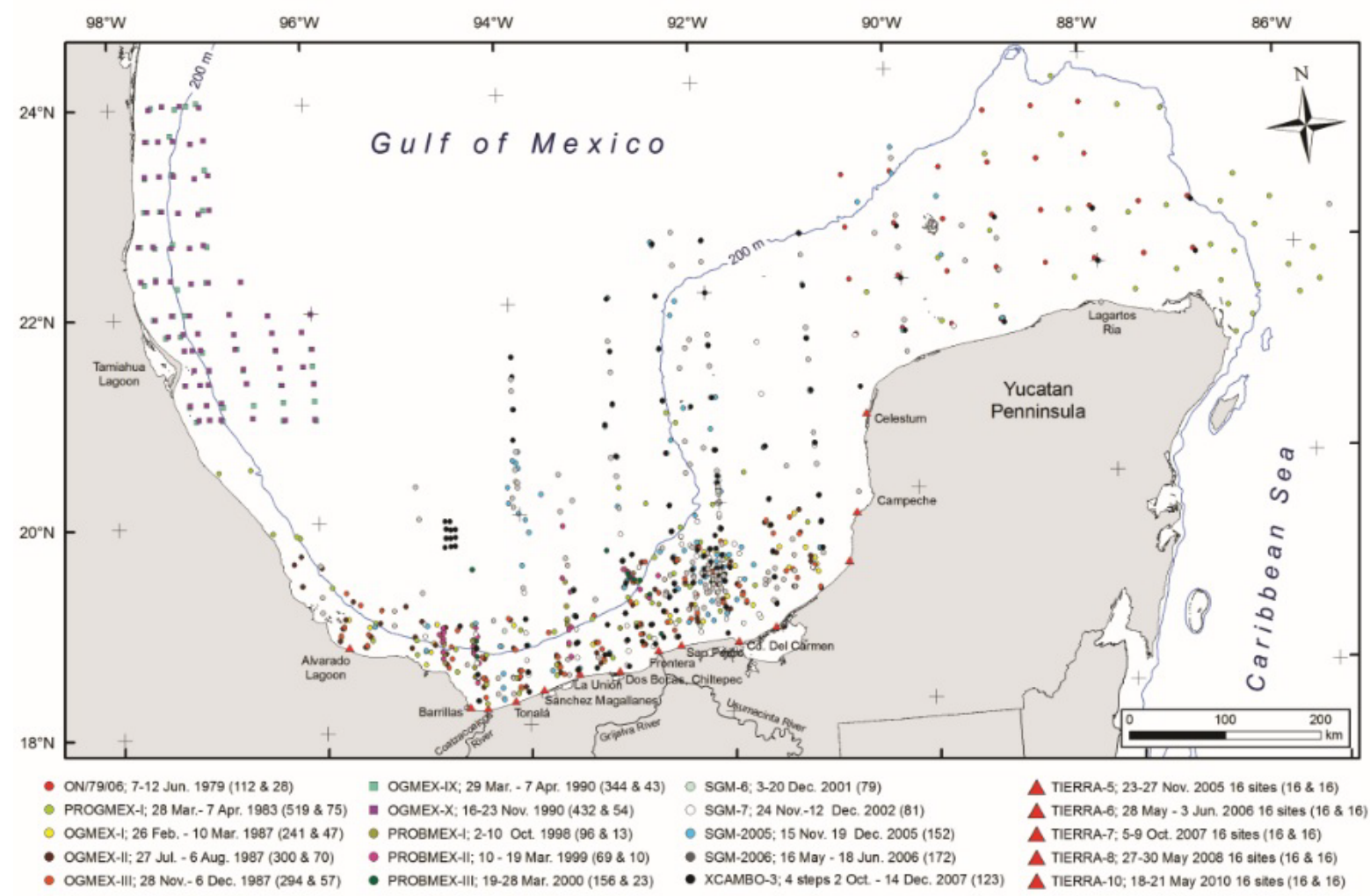

Figure 1: Study area. Color points show 647 sampling sites during 20 oceanographic cruises were surveyed from June 1979 to December 2010 in the southern Gulf of Mexico.

as several lagoons that contribute to coastal outwelling [22-24]. More information concerning this area may be found in Yañez-Arancibia et al. [25]. The Yucatan Shelf is also greatly influenced by an upwelling in the north of Cape Catoche $[26,27]$. Consequently, while one portion of this water flows towards the west, the other part moves towards the east [28].

This region is a highly productive fishing area, and profitable for the oil industry. Both activities have turned this region into an economically important area, but potentially critical as well due to continuous oil spills and the presence of toxic substances in untreated water that affect this region [29]. It is important to recognize marine diatoms as indicators of modern changes in oceanographic conditions [5], and likewise for oil and gas exploration [30].

\section{Sampling strategy and laboratory analyses}

This diatom checklist was compiled from 20 oceanographic cruises between July 1979 and May 2010. Most surveys were done on board the R/V "Justo Sierra". During this period 647 sites were sampled (sometimes more than once) and the sampling stations covered the entire southern Gulf. Discrete water samples were taken by a CTD Neil Brown with a rosette of Niskin bottles and were preserved with acidified Lugol's solution. Vertical net samples were collected using 20 $\mu \mathrm{m}$ and $35 \mu \mathrm{m}$ mesh-sized plankton nets within $5 \mathrm{~m}$ from the bottom to the surface were carried out at each sampling site and the samples were preserved with $2 \%$ neutralized formaldehyde. Most species were identified in water mounts or on an inverted light microscope. In addition, acid-cleaned samples were mounted in Naphrax [31]. In some cases, transmission or scanning electron microscope allowed us the identification of difficult species of the genera Amphora, Pseudonitzschia, Thalassiosira, Psammodictyon and many small taxa. The reported species composition is based upon the database sponsored by The National Council for the Study and Conservation of Biodiversity (CONABIO) [32,33].

\section{Species identification}

The identification of some species was achieved using classic books $[8,11,34-42]$, but specialized literature was needed for specific taxa. In addition, some diatom databases on web sites were also consulted $[10,43,44]$. Images in several databases illustrated intraspecific variability. Light and eventually electron microscopes were commonly used for routine analyses. In addition databases were used to review valid names to improve their spelling, and to standardize authorized names. Besides, there are pertinent links to obtain additional information, unless they are specifically unauthorized.

This checklist comes from a phytoplankton database that is at a medium stage of development. It contains mainly light micrograph images from 25 oceanographic cruises carried out at the SGM, also electron microscope photographs, light microscope digital images, information about samples, a short description of each species as well as a collection of permanent mounted slides from most net samples. This collection is known as the MEX-UNAM Diatom Collection and is stored at the Instituto de Ciencias del Mar y Limnología from the Universidad Nacional Autónoma de México under curation of the corresponding author. 
Citation: Licea S, Moreno-Ruiz JL, Luna R (2016) Checklist of Diatoms (Bacillariophyceae) from the Southern Gulf of Mexico: Data-Base (1979-2010) and New Records. J Biodivers Endanger Species 4: 174. doi: 10.4172/2332-2543.1000174

Page 3 of 7

\section{Habitat Species}

BW Achnanthes curvirostrum

FW Achnanthes exigua

NH Achnanthes manifera

FW Achnanthes ventralis (Krasske)

FW Achnanthidium exiguum var. heterovalvum (G.Krasske)

M Actinocyclus circellus

M Actinocyclus curvatulus

M Actinocyclus octonarius var. crassus

M Actinocyclus octonarius var. ralfsii

M $\quad$ Actinocyclus octonarius var. sparsus

M Actinocyclus octonarius var. tenellus

M Actinocyclus subtilis

M Actinoptychus campanulifer

$\mathrm{NH} \quad$ Actinoptychus minutus

M Actinoptychus octonarius

M Actinoptychus senarius

M Actinoptychus splendens

$\mathrm{NH} \quad$ Actinoptychus vulgaris

M Alveus marinus

M Amphicocconeis disculoides

M Amphora angusta

M Amphora arenaria

$\mathrm{NH} \quad$ Amphora bacillaris

$\mathrm{NH} \quad$ Amphora bigibba

$\mathrm{NH} \quad$ Amphora bioculata

NH Amphora contracta

NH Amphora costata var. inflata

$\mathrm{NH} \quad$ Amphora decussata

$\mathrm{NH} \quad$ Amphora laevis

FW Amphora ovalis

FW Amphora pediculus

M Amphora proteus

NH Amphora rhombica

M Asterionellopsis glacialis

M Asterolampra marylandica

M Asteromphalus arachne

M Asteromphalus cleveanus

M Asteromphalus flabellatus

M Asteromphalus heptactis

$\mathrm{NH} \quad$ Asteromphalus ingens

$\mathrm{NH} \quad$ Asteromphalus robustus

M Asteromphalus sarcophagus

$\mathrm{NH} \quad$ Asteromphalus shadboltianus

$\mathrm{NH} \quad$ Asteromphalus stellatus

M Attheya septentrionalis

FW Aulacoseira granulata

FW Aulacoseira granulata var. angustissima

FW Aulacoseira italica

M Azpeitia neocrenulata

M Azpeitia nodulifera

$\mathrm{NH} \quad$ Bacillaria paxillifera

M Bacteriastrum comosum

M Bacteriastrum delicatulum

M Bacteriastrum elegans

M Bacteriastrum elongatum

M Bacteriastrum furcatum

\begin{tabular}{l|l} 
M & Bacteriastrum hyalinum
\end{tabular}

M Bellerochea horologicalis

M $\quad$ Biddulphia biddulphiana

M Biddulphia rhombus \begin{tabular}{l|l}
\hline M & Biddulphia tridens \\
\hline M & Bleakeleya notata
\end{tabular}

M Bleakeleya notata

FW Caloneis amphisbaena

BW Caloneis liber

$\mathrm{NH} \quad$ Campylodiscus braziliensis

M/FW Campylodiscus clypeus

M $\quad$ Campylodiscus decorus

M Campylodiscus samoensis

M Campylosira cymbelliformis

M $\quad$ Carinasigma rectum

M Catacombas gaillonii

M Cerataulina pelagica

$\mathrm{NH} \quad$ Cerataulus californicus

M Cerataulus smithii

NH Cerataulus turgidus

M Ceratoneis closterium

M Chaetoceros affinis

M Chaetoceros anastomosans

M Chaetoceros atlanticus var. neapolitanus

M Chaetoceros atlanticus

M Chaetoceros borealis

M $\quad$ Chaetoceros brevis var. brevis

M Chaetoceros coarctatus

M $\quad$ Chaetoceros compressus

M Chaetoceros concavicornis

M Chaetoceros constrictus

M Chaetoceros curvisetus

M Chaetoceros dadayi

M Chaetoceros danicus

M Chaetoceros debilis

M $\quad$ Chaetoceros decipiens

M Chaetoceros dichaeta

M $\quad$ Chaetoceros didymus var. didymus

M Chaetoceros difficilis

M Chaetoceros diversus

M Chaetoceros eibenii

M Chaetoceros gracilis

M Chaetoceros laciniosus

M Chaetoceros lorenzianus

M Chaetoceros messanensis

M Chaetoceros minimus

M Chaetoceros pelagicus

M Chaetoceros pendulus

M Chaetoceros perpusillus

M Chaetoceros peruvianus

M Chaetoceros protuberans

M Chaetoceros pseudocurvisetus

M Chaetoceros radicans

M Chaetoceros rostratus

M Chaetoceros seiracanthus

M Chaetoceros simplex

M Chaetoceros socialis

M $\quad$ Chaetoceros subtilis

M $\quad$ Chaetoceros subtilis var. abnormis

M Chaetoceros tenuissimum

M Chaetoceros teres

M Chaetoceros tetrastichon

M Chaetoceros tortissimus

M $\quad$ Chaetoceros wighamii

M Chaetoceros willei

M Climacodium frauenfeldianum 
Citation: Licea S, Moreno-Ruiz JL, Luna R (2016) Checklist of Diatoms (Bacillariophyceae) from the Southern Gulf of Mexico: Data-Base (1979-2010) and New Records. J Biodivers Endanger Species 4: 174. doi: 10.4172/2332-2543.1000174

Page 4 of 7

\begin{tabular}{|c|c|c|c|}
\hline M & Climacosphenia moniligera & M & Entomoneis gigantea \\
\hline $\mathrm{NH}$ & Cocconeis britannica & M & Entomoneis paludosa var. paludosa \\
\hline $\mathrm{M} / \mathrm{FW}$ & Cocconeis placentula var. placentula & M & Entomoneis pulchra \\
\hline FW & Cocconeis placentula var. euglypta & $\mathrm{NH}$ & Envekadea pseudocrassirostris \\
\hline M & Cocconeis pseudomarginata & FW & Epithemia adnata \\
\hline $\mathrm{NH}$ & Cocconeis scutellum & M & Eucampia cornuta \\
\hline M & Colliculoamphora reichardtiana & M & Eucampia zodiacus \\
\hline M & Corethron hystrix & M & Eunotogramma laeve \\
\hline $\mathrm{NH}$ & Coscinodiscopsis jonesiana & M & Eupodiscus radiatus \\
\hline M & Coscinodiscus alboranii & M & Extubocellulus spinifer \\
\hline M & Coscinodiscus asteromphalus & M & Falcula hyalina \\
\hline M & Coscinodiscus centralis & BW & Fallacia pygmaea \\
\hline M & Coscinodiscus concinnus & FW & Fragilaria acus \\
\hline M & Coscinodiscus gigas & FW & Fragilaria brevistriata \\
\hline M & Coscinodiscus granii & $\mathrm{NH}$ & Fragilaria brevistriata var. elliptica \\
\hline M & Coscinodiscus jonesianus & $\mathrm{NH}$ & Fragilaria goulardii var goulardii \\
\hline M & Coscinodiscus marginatus & FW & Fragilaria tenera \\
\hline M & Coscinodiscus perforatus & M & Fragilariopsis doliolus \\
\hline M & Coscinodiscus radiatus var. radiatus & M & Fragilariopsis kerguelensis \\
\hline M & Coscinodiscus reniformis & FW & Gomphonema angustatum \\
\hline $\mathrm{NH}$ & Coscinodiscus rothii & FW & Gomphonema affine \\
\hline M & Coscinodiscus wailesii & FW & Gomphonema gracile \\
\hline FW & Craticula accomoda & FW & Gomphonema gracile var. naviculoides \\
\hline FW & Craticula ambigua & FW & Gomphonema intricatum \\
\hline $\mathrm{M} / \mathrm{FW}$ & Craticula halophila & M & Gossleriella tropica \\
\hline FW & Craticula vixvisibilis & M & Grammatophora angulosa \\
\hline FW & Cyclotella choctawhatcheeana & $M$ & Grammatophora marina \\
\hline FW & Cyclotella litoralis & M & Guinardia cylindrus \\
\hline FW & Cyclotella meneghiniana & M & Guinardia delicatula \\
\hline FW & Cyclotella stelligera & $M$ & Guinardia flaccida \\
\hline FW & Cyclotella striata & M & Guinardia striata \\
\hline FW & Cyclotella stylorum & FW & Gyrosigma acuminatum \\
\hline M & Cymatonitzschia marina & M & Gyrosigma balticum \\
\hline M & Cymatosira Iorenziana & M & Gyrosigma fasciola \\
\hline FW & Cymbella mexicana & FW & Gyrosigma macrum \\
\hline M & Dactyliosolen fragilissimus & M & Halamphora capitata \\
\hline M & Dactyliosolen phuketensis & M & Halamphora clara \\
\hline M & Delphineis angustata & BW & Halamphora coffeiformis \\
\hline M & Delphineis minutissima & M & Halamphora exigua \\
\hline M & Delphineis surirella & FW & Halamphora perpusilla \\
\hline FW & Denticula kuetzingii & M & Halamphora terroris \\
\hline M & Detonula pumila & FW & Halamphora veneta \\
\hline M & Dimeregramma marinum & M & Haslea frauenfeldii \\
\hline $\mathrm{NH}$ & Diploneis bombus & M & Haslea gigantea \\
\hline M & Diploneis coffaeiformis & M & Haslea spicula \\
\hline $\mathrm{NH}$ & Diploneis contigua var. eugenia & M & Haslea wawrikae \\
\hline FW & Diploneis crabro & M & Helicotheca tamesis \\
\hline $\mathrm{NH}$ & Diploneis decipiens var. parallela & M & Hemiaulus hauckii \\
\hline $\mathrm{NH}$ & Diploneis lineata & M & Hemiaulus membranaceus \\
\hline $\mathrm{NH}$ & Diploneis obliqua & M & Hemiaulus sinensis \\
\hline $\mathrm{M} / \mathrm{FW}$ & Diploneis ovalis & M & Hemidiscus cuneiformis \\
\hline M & Diploneis papula & M & Hemidiscus cuneiformis var. orbicularis \\
\hline FW & Diploneis puella & M & Hemidiscus cuneiformis var. ventricosus \\
\hline $\mathrm{M} / \mathrm{FW}$ & Diploneis smithii & M & Isthmia nervosa \\
\hline $\mathrm{NH}$ & Diploneis subadvena & M & Lampriscus shadboltianum \\
\hline M & Diploneis vacillans var. renitens & M & Lauderia annulata \\
\hline $\mathrm{NH}$ & Diploneis vetula & M & Leptocylindrus danicus \\
\hline M & Diploneis weissflogii & M & Leptocylindrus mediterraneus \\
\hline M & Ditylum brightwellii & $\mathrm{NH}$ & Leptocylindrus minimus \\
\hline FW & Encyonema minutum var. pseudogracilis & $\mathrm{NH}$ & Licmophora abbreviata \\
\hline M & Entomoneis alata & $\mathrm{NH}$ & Licmophora communis \\
\hline
\end{tabular}




\begin{tabular}{|c|c|}
\hline M & Licmophora ehrenbergii \\
\hline BW & Licmophora flabellata \\
\hline M & Licmophora gracilis \\
\hline $\mathrm{NH}$ & Licmophora remulus \\
\hline M & Lioloma delicatulum \\
\hline M & Lioloma elongatum \\
\hline M & Lioloma pacificum \\
\hline M & Lithodesmium undulatum \\
\hline $\mathrm{NH}$ & Lyrella clavata \\
\hline M & Lyrella exsul \\
\hline M & Lyrella hennedyi \\
\hline $\mathrm{NH}$ & Lyrella lyra \\
\hline M & Mastogloia angulata \\
\hline M & Mastogloia binotata \\
\hline FW & Mastogloia erythraea \\
\hline M & Mastogloia rostrata \\
\hline M & Melosira moniliformis \\
\hline M & Melosira nummuloides \\
\hline FW & Melosira varians \\
\hline FW & Meuniera membranacea \\
\hline FW & Minidiscus trioculatus \\
\hline BW & Navicula cincta \\
\hline M & Navicula directa \\
\hline $\mathrm{NH}$ & Navicula distans \\
\hline $\mathrm{NH}$ & Navicula pelagica \\
\hline FW & Navicula pennata \\
\hline $\mathrm{M} / \mathrm{FW}$ & Navicula tripunctata \\
\hline M & Neocalyptrella robusta \\
\hline M & Neodelphineis indica \\
\hline M & Neodelphineis pelagica \\
\hline M & Neodenticula \\
\hline M/FW & Nitzschia acicularis \\
\hline $\mathrm{NH}$ & Nitzschia angularis var. affinis \\
\hline M & Nitzschia bicapitata \\
\hline $\mathrm{NH}$ & Nitzschia bifurcata \\
\hline $\mathrm{NH}$ & Nitzschia braarudii \\
\hline M & Nitzschia capuluspalae \\
\hline M & Nitzschia dietrichii \\
\hline FW & Nitzschia dissipata \\
\hline $\mathrm{NH}$ & Nitzschia fluminensis \\
\hline $\mathrm{M} / \mathrm{FW}$ & Nitzschia frustulum \\
\hline $\mathrm{NH}$ & Nitzschia gandersheimiensis \\
\hline M & Nitzschia interruptestriata \\
\hline M & Nitzschia longissima \\
\hline M & Nitzschia ossiformis \\
\hline FW & Nitzschia ovalis \\
\hline M & Nitzschia pacifica \\
\hline $\mathrm{NH}$ & Nitzschia palea var. debilis \\
\hline FW & Nitzschia palea \\
\hline $\mathrm{NH}$ & Nitzschia sicula var. sicula \\
\hline $\mathrm{NH}$ & Nitzschia sigma var. Sigma \\
\hline FW & Nitzschia sigmoidea \\
\hline $\mathrm{NH}$ & Nitzschia socialis \\
\hline M & Nitzschia spathulata \\
\hline $\mathrm{NH}$ & Nitzschia vidovichi \\
\hline M & Odontella aurita \\
\hline M & Odontella longicruris \\
\hline M & Odontella regia \\
\hline M & Odontella turgida \\
\hline $\mathrm{NH}$ & Oestrupia musca \\
\hline M & Palmerina hardmaniana \\
\hline
\end{tabular}

\begin{tabular}{|l|l|}
\hline M & Paralia sulcata \\
\hline NH & Petroneis granulata \\
\hline FW & Pinnularia acrosphaeria \\
\hline FW & Pinnularia biceps \\
\hline FW & Pinnularia borealis \\
\hline FW & Placoneis elginensis \\
\hline NH & Plagiodiscus nervatus \\
\hline M & Plagiogrammopsis vanheurckii \\
\hline M & Planktoniella sol \\
\hline FW & Planothidium lanceolatum \\
\hline M & Pleurosigma acutum \\
\hline M & Pleurosigma angulatum var. angulatum \\
\hline M & Pleurosigma diversestriatum \\
\hline M & Pleurosigma normanii \\
\hline M & Pleurosigma rhombeum \\
\hline M & Podocystis adriatica \\
\hline M & Podosira stelligera \\
\hline M & Proboscia alata \\
\hline M & Proboscia alata \\
\hline M & Proboscia eumorpha \\
\hline M & Proboscia indica \\
\hline M & Psammodictyon constrictum \\
\hline M & Psammodictyon panduriforme \\
\hline FW & Psammodictyon panduriforme var. minor \\
\hline M & Psammodiscus nitidus \\
\hline NH & Pseudoguinardia recta \\
\hline
\end{tabular}

Table 1: Checklist of 430 taxa from the southern Gulf of Mexico identified mainly by the light microscopy in water and net samples collected between June 1979 and December 2010. Species in bold letters are new records from southern the Gulf of Mexico. Underlined species were identified under the electron microscope. BW: Brackish Water Species; FW: Fresh Water Species; M: Marine Species; NH: Habitat Not Recorded. Ecology information retrieved mostly from Guiry and Guiry [10] and Horton et al. [44].

\section{Results and Discussion}

\section{Collection and identification techniques}

This is the first account of diatoms from the SGM. A total of 430 taxa are recorded and no synonyms are listed in Table 1 . The great majority of species are tropical, subtropical or cosmopolitan. Some species have been recorded as brackish-water, fresh water and benthic. Around $45 \%$ of the diatoms were identified during analysis of water samples with the inverted microscope (Carl Zeizz ICM405) to identify forms and structures of colonies. The standard phase contrast Carl Zeizz photomicroscope was useful to observe other structures of taxonomic importance (striation, rimoportulae and fultoportulae etc.).

The abundance of suspended sediments in the coastal zone hinders species identification, especially of "small centrics and pennates", and even medium-sized species of Thalassiosira, Diploneis, Fragilaria Lyrella, Navicula and Nitzschia. However some $90 \%$ of the recorded species can be identified on permanent slides under a light microscopy with a magnification up to X1200 (oil immersion, phase contrast and Nomarski optics). Scanning and transmission electron microscopes were required to identify certain species such as Pseudonitzschia, Minidiscus and many other small-celled taxa. There are several sampling techniques to study diatom species because there is a considerable variation in size, from approximately 3-5 $\mu \mathrm{m}$ to $1000 \mu \mathrm{m}$. Besides, it must be taken into account that rare species are usually low represented in water samples and net tows are selective. 


\section{Identification problems}

It was difficult to distinguish closely related species even on permanent mounts since some descriptions were insufficient or inadequate. An example is the characterization of valves; they could be 'rectangular', 'capitate', 'small', 'neat' or 'lanceolate'. Their morphological variation can be very broad, even if the striation is measured. An electron microscopy is necessary to solve this problem. Diatoms are extremely diverse and there are many species that have not been described yet, the species delimitation is still controversial.

\section{The use of databases}

Online databases have been very useful, especially those that provide additional bibliographic information and species distributions. Some online diatom collections and databases offer open access with descriptions, images, environmental and bibliographic data, and in some cases, the use of software for various purposes. It is important to recognize that there is a continuous need to update taxonomy and it requires a careful surveillance. We were able to review all species listed on Table 1 with specialized literature and with on line databases since they provided us with the necessary information to take a decision.

A correct identification of every species in a given region is of great importance, since every taxon plays a role in the ecosystem. In particular, small species $(3-8 \mu \mathrm{m})$ are difficult to identify and an electron microscope is frequently required. On occasions, some of these species may become very abundant and widely distributed; they may even have blooms that affect the ecosystem. In the studied region we found several species with these characteristics: Minidiscus trioculatus, Cyclotella litoralis, Delphineis minutissima, Leptocylindrus minimus, Nitzschia bifurcata, Thalassiosira allenii, and Pseudonitzschia among others. The contribution of river flow and the discharge of several coastal lagoons into the region could explain the presence of fresh and brackish water species along the coast. Examples of these are many species of the genera Amphora, Achnanthes, Cyclotella, Diploneis, Navicula, and Nitzschia.

\section{The potential use of validated diatoms checklists}

In the past there was a tendency to erect taxa on the basis of tiny, subtle differences in morphology, sometimes in individual specimens without attempting to establish their stability. On the other hand, in the last 40 years, new genera or living diatoms have been discovered.

Validated and updated checklists are essential for ecological studies involving monitoring assessments or changes in the species composition in a given site. Without these checklists it would be impossible to detect changes in the structure of a community and the use of indicator species would be limited. There is a long-standing debate regarding the ecology of phytoplankton and this has been the controversy underlying a non-uniform distribution of species. A possible answer for the disagreements is that it depends on the spatial scale. With a scale of hundred kilometers, the differences between diatom communities are utterly related to geographic or hydrographic features. We were able to establish four regions in the southern Gulf of Mexico by using species association as part of this checklist [16]. Other authors have identified similar regions but using other organisms as a reference [45]. Another potential use for a diatom database is the detection of non-native species introduced via ship ballast water [30].

There is great risk that human activities could cause a loss in diatom biodiversity, it is fundamental to know about changes in species composition and its implications for ecosystem function. There is an urgent need to understand the marine ecosystems and other problems derive from natural and anthropogenic sources.

This checklist needs to be constantly updated, which is useful as a reference for ecological work considering that diatoms are good indicators of environmental changes. A good knowledge of the species composition is important to be competent in the recognition of changes in the paleo-environment.

Diatom species could indicate substantial differences and the degree of endemism in different regions, since they are indicators of the discharge of rivers and coastal lagoons [4,5]. Furthermore, diatoms are also useful for historical water quality assessments, bio monitoring and climate change., and additionally a checklist is important for the detection of non-native species, introduced by ballast water.

\section{Acknowledgment}

The authors thank the crew members of the R/V "Justo Sierra" and the participating scientists and students in the PROGMEX, OGMEX and SGM oceanographic cruises. Partial support was provided by CONABIO (grants: FB683/ S088 and A0012/2002). J. Manuel Figueroa-MahEng by Figure 1 edition. Héctor Alexander-Valdes provided technical assistance. We acknowledge the Academic Writing Team of the Coordinación de Estudios de Posgrado, UNAM for their help to improve this manuscript.

\section{References}

1. Yool A, Tyrrell $T$ (2003) Role of diatoms in regulating the ocean's silicon cycle. Glob Biogeochem Cycles 17: 1103

2. Dam H V, Mertens A, Sinkeldam J (1994) A coded checklist and ecological indicator values of freshwater diatoms from the Netherlands. Netherl $\mathrm{J}$ Aquat Ecol 28: 117-133.

3. Edwards M, Richardson AJ (2004) Impact of climate change on marine pelagic phenology and trophic mismatch. Nature 430: 881-884.

4. Trobajo R, Sullivan M (2010) Applied diatom studies in estuaries and shallow coastal environments. The Diatoms Applications for the Environmental and Earth Sciences, Cambridge University Press, Cambridge, UK, pp: 309-323.

5. Romero OE, Armand LK (2010) Marine diatoms as indicators of modern changes in Oceanographic conditions. The Diatoms Applications for the Environmental and Earth Sciences $\left(2^{\text {nd }} e d n\right.$.) Cambridge University Press, Cambridge, UK, pp: 373-400.

6. Schlüter M, Kraberg A, Wiltshire KH (2012) Long-term changes in the seasonality of selected diatoms related to grazers and environmental conditions. J Sea Res 67: 91-97.

7. Werner D (1977) Introduction with a note on taxonomy. Werner D. The biology of diatoms, Botanical Monographs, University of California Press, California 13: $1-17$.

8. Hasle GR, Syvertsen EE (1997) Identifying Marine Phytoplankton. Academic Press, California, USA

9. Krayesky DM, Castillo EMD, Zamudio E, Norris JN, Frederic S (2009) Diatoms (Bacillariophyta) of the Gulf of Mexico. Gulf of Mexico: Its Origins, Waters, and Biota, 8 College Station Texas A\&M University Press, pp: 379-453.

10. Guiry MD, Guiry GM (2016) AlgaeBase. World-wide electronic publication National University of Ireland, Galway.

11. Schmidt A, Schmidt M, Fricke F, Heiden H, Mülle, O, Hustedt F (1874-1959) Atlas der Diatomacenkunde. Reprinted by Otto Koeltz Antiquariat Koenigstein Taunus. Leipzig, p: 480.

12. Okolodkov YB (2003) A review of Russian plankton research in the Gulf of Mexico and the Caribbean in the 1960-1980s. Hidrobiologica 13: 207-221.

13. Moreno-Ruiz JL, Soto JP, Zamudio ME, Becerril DUH, Licea S (1993) Morphology and taxonomy of Chaetoceros diversus Cleve (Bacillariophyceae), with reference to material from the Southern Gulf of México. Diatom Res 8: 419-428.

14. Moreno JL, Licea S (1994) Morphology of three species of Coscinodiscus Ehrenberg from South Gulf of México and North Pacific of México. Calif Acad Sci 17: 113-127.

15. Licea S (1994) Thalassiosira species from the Southern Gulf of Mexico. Calif Acad Sci 17: 311-335. 
Citation: Licea S, Moreno-Ruiz JL, Luna R (2016) Checklist of Diatoms (Bacillariophyceae) from the Southern Gulf of Mexico: Data-Base (1979-2010) and New Records. J Biodivers Endanger Species 4: 174. doi: 10.4172/2332-2543.1000174

16. Licea S, Zamudio ME, Moreno-Ruiz JL, Luna R (2011) A suggested local regions in the Southern Gulf of Mexico using a diatom data-base (1979-2002) and oceanic hydrographic features. J Environ Biol 32: 443-453.

17. Ferrario M, Almandoz G, Licea S, Gariboti I (2008) Species of Coscinodiscus from the Gulf of Mexico, Argentina and Antarctic waters: Morphology and distribution. Nova Hedwigia 133: 187-216.

18. Hernandez-Becerril DU, Granados CF (1998) Species of the diatom genus Chaetoceros (Bacillariophyceae) in the plankton from the southern Gulf of Mexico. Botanica Marina 41: 505-519.

19. Hernandez-Becerril DU (1998) Morphological study of the marine planktonic diatom Chaetoceros okamurai (Chaetocerotales, Bacillariophyceae) from the Gulf of Mexico. Phycol Res 46: 11-15.

20. Hernandez-Becerril DU, Garcia-Resendiz JA, Salas-de-Leon DA, MonrealGomez M, Signoret-Poillon M, et al. (2008) Nanoplankton fraction in the phytoplankton structure in the southern Gulf of Mexico (April 2000). Ciencias Marinas 34: 77-90.

21. Salas-de-Leon DA, Monreal-Gómez MA, Velasco Mendoza H, Flores MAD, Ramírez JA (2009) Hydrodynamic modeling and trajectory of suspended particles in the southern Gulf of Mexico. PEMEX and the Environmental Health of the Campeche Sonda, Mexico, pp: 155-168.

22. Alatorre MA, Ruiz F, Salas de Leon D (1987) Effect of the passage of cold atmospheric fronts on the Bay of Campeche. Annual Meeting Report. Union Geophysics Mexican, Mexico, pp: 186-193.

23. Zavala-Hidalgo J, Gallegos-García A, Martinez B, López S, Morey I, et al. (2006) Seasonal upwelling on the Western and Southern Shelves of the Gulf of Mexico. Ocean Dynam 56: 333-338.

24. Zavala-Hidalgo J, Romero-Centeno R, Mateos-Jasso A, Morey SL, MartinezLopez B (2014) The response of the Gulf of Mexico to wind and heat flux forcings: What has been learned in the last 20 years? Atmosfera 27: 317-334.

25. Yanez-Arancibia A, Day JW, Reyes E (2013) Understanding the coastal ecosystem-based management approach in the Gulf of Mexico. J Coastal Res 63: 244-262

26. Cochrane JD (1969) Water and circulation on Bank of Campeche in May. Bull Jpn Soc Fish Oceanogr Spec pp: 123-128.

27. Merino M (1997) Upwelling on the Yucatan Shelf: hydrographic evidence. J Mar Syst 13: 202-121.

28. Furnas MJ, Smayda TJ (1987) Inputs of subthermocline waters and nitrate onto the Campeche Bank. Continental Shelf Res 7: 161-175.

29. Velez GP, Botello AV (2005) Hydrocarbon levels in the Gulf of Mexico. Gulf of Mexico, Pollution and Environmental Impact and Trends. Autonomous University of Campeche, National Autonomous University of Mexico, National Institute of Ecology, Mexico, pp: 269-298.
30. Krebs W, Gladenkov AY, Jones GD (2010) Diatoms in oil and gas exploration The Diatoms Applications for the Environmental and Earth Sciences. Cambridge University Press, pp: 523-533.

31. Hasle GR, Fryxell GA (1970) Diatoms: cleaning and mounting for light and electron microscopy. Trans Am Microsc Soc 89: 469-474

32. Licea S (1998) Diatoms (Bacillariophyceae) most abundant and frequent on the continental shelf and slope of the southern Gulf of Mexico, Mexico.

33. Licea S, Luna R, Resendis MEZ, Moreno JL, Soto J (2003) Diatoms (Bacillariophyceae) and Dinoflagellates (Dinophyceae) more frequent in the southern region of the Gulf of Mexico.

34. Hustedt F (1930) Die Kieselalgen Deutschlands, Osterreichs und der Schweiz, Rabenhorst Kryptogamen-Flora von Deutshland, Osterreichs und der Schweiz. J Repring Co, New York 7: 1-920.

35. Hustedt F (1959) The diatom of Germany, Austria and Switzerland. Rabenhors Kryptogamen flora of Deutshland, Osterreichs and Switzerland. J Repring Co, New York 7: 1-845.

36. Hustedt F (1961) The diatom of Germany, Austria and Switzerland. Rabenhorst Kryptogamen flora of Deutshland, Osterreichs and Switzerland. J Repring Co New York 7: 1-816.

37. Hendey NI (1964) An introductory account of the smaller algae of British coasta waters. Part 5: Bacillariophyceae (Diatoms), Ministry of Agriculture, Fisheries and Food, Fishery Investigations IV, HMSO, London, pp: 1-317.

38. Simonsen R (1974) The diatom plankton of the Indian Ocean Expedition of RV "Meteor" 1964-1965. Meteor Forschungsergebnisse Reihe D 19: 1-107.

39. Simonsen R (1987) Atlas and Catalogue of the Diatom Types of Friedrich Hustedt. In: Cramer J (ed.) Berlin, pp: 1-525.

40. Simonsen R (1987a) Atlas and Catalogue of the Diatom Types of Friedrich Hustedt. In: Cramer J (ed.), pp: 1-395.

41. Simonsen R (1987b) Atlas and Catalogue of the Diatom Types of Friedrich Hustedt. In: Cramer J (ed.), pp: 396-772.

42. Round FE, Crawford RM, Mann DG (1990) The Diatoms, biology and Morphology of the genera. Cambridge University Press, Cambridge, pp: 1-747.

43. Index Nominum Algarum (2015) University Herbarium, University of California Berkeley.

44. Horton T, Kroh A, Bailly N, Boury-Esnault N, Brandão SN (2016) World Register of Marine Species.

45. Flores-Coto C, Sanvicente-Anorve L, Zavala-Garcia F, Zavala-Hidalgo J, Funes Rodriguez R (2014) Environmental factors affecting structure and spatia patterns of larval fish assemblages in the southern Gulf of Mexico. Rev Biol Mar Oceanogr 49: 307-321. 